\title{
Making Voices: Identity, Poeclectics and the Contemporary British Poet ${ }^{1}$
}

\author{
Mario Petrucci \\ School of Arts and Humanities, Oxford Brookes University, Oxford, UK
}

The concept of Poeclectics is described, and used to explore the vitality, diversification and complexity of voice currently exhibited among British poets. The author also examines, through a Poeclectic lens, specific aspects of literary output in order to demonstrate a growing engagement between their means of funding and profound contemporary issues of personal-creative identity. The importance of collaboration among artists is highlighted, principally through the ShadoWork project, thereby introducing the terms polyvocal, co-vocal and multi-vocal. Some key Poeclectic issues are illustrated through site-specific and 'self-performing' work, including a community-based Year of the Artist commission and the unique Poetry Hunt currently on view at the Imperial War Museum. The author concludes with a thorough assessment of the dangers and opportunities presented by Poeclectic practice (particularly in terms of artistic integrity, the modern self and conflict resolution), raising the question of how best to support poets in the growing sector of public commissions, and with a closing emphasis on urban regeneration and community identity.

doi: 10.2167/new058.0

Keywords: community, identity, Poeclectics, poetry, ShadoWork, voice

\section{Author Identity and 'Poeclectics'}

What can we make of the increased activity, in recent years, of British poets in community projects, residencies and public spaces, including cyberspace? Is the UK poetry scene opening up to a greater range of method, siting and voice? Are notions of literary value shifting towards the communal?

It is instructive to consider such questions in the light of 'Poeclectics'. This is a concept I have been developing for a number of years (Petrucci, 2001), primarily as a means of encompassing a trend in contemporary British poetry to utilise all kinds of style, subject, voice, register and form. The coinage of the term fully embodies and encapsulates that trend. Poeclectics welds a powerful sense of 'making' (Greek: poiesis) to the desire to work inventively with a variety of sources and processes (eklegein: to choose out, select). It certainly involves established intertextual techniques in poetry (such as pastiche and parody) but also embraces (as does the avant-garde) any stimulus, setting or prompt as a means of generating or siting texts. A key contributor to the Poeclectic mode is the multiple use of voices, masks and personae, an approach that many well known poets now emphasise. True, that magpie tendency, that dappled self, is hardly new to literature. It has been expressed for centuries through a variety of means, 
including the dialogues in novels and the casts of plays; but its current significance in poetry is, I suggest, a matter both of degree and of the way in which it now fertilises and defines the work of so many individual writers. Jo Shapcott's My Life Asleep (1998), for instance, allows confessional poems and lyrical translations of Rilke to rub shoulders with a talking quark, Mrs Noah and a rhinoceros. Carol Ann Duffy's (1999) monologues, too, exemplify this now familiar aspect of Poeclectics.

There is far more to this trend, however, than mere character-making or ventriloquism. Poeclectics - in my conception of it - includes any literary practice that is discursive and/or hybrid, and many poets are now clearly mixing disciplines and genres (Dannie Abse's straddling of poetry and medicine; David Morley's poetic illuminations of science). There has also been a burgeoning and expansion of voice as a result of social and geographic mobility, and through diverse cultural influences (Benjamin Zephaniah, Moniza Alvi, Bernadine Evaristo, Daljit Nagra, to name but a few). Indeed, we may link Poeclectics with David Kennedy's assessment of British poetry after the Movement, for which 'any cultural origin or position is available and equally valid' (Kennedy, 1996: 20) and where

... many poets have chosen to question the relationship between authenticity and artifice... by locating - or asking the reader to locate - the voice of an individual poem on a sliding scale between the apparent self of the poet and an explicit character or persona. (Kennedy, 1996: 261)

That phrase 'the voice of an individual poem' highlights how, in Poeclectics, the voice often varies according to a poem-by-poem pulse. Each poem tends to be self-sufficient, falling into its own 'quantum level' of voice. The influential poem-centred anthology Emergency Kit (Shapcott \& Sweeney, 1996) is one sign of this new focus on the individual poem. The rise of poetry competitions may represent a further effect (or cause?) in this. All in all, then, the notion of 'voice' in poetry has much greater fluidity and diversity now than it had in Larkin's time, with multiple voices being deployed far more freely and in a more conspicuous manner. Naturally, the Poeclectic writer may still be identifiable behind and through the work, but not because of a single overt personality or style.

Another facet of Poeclectics, as I see it, is its depth of openness to 'the other'. Gregson (1996: 7) notes the contemporary writer's 'profound sense that the self has no meaning except in interrelation with others'. This pursuit of otherness (and the self grappling with it) is now a crucial mode in the re/construction of self in poetry, particularly as our literature begins to embrace minority voices. Poeclectics facilitates a growing consciousness of self/non-self by enlarging the poet's palette, offering a challenge - as does postmodernism - to the Romantic notion that the poet is identifiable with a solitary 'core' persona. However, postmodernism and Poeclectics pose this challenge in subtly different ways. Poeclectics is a little like the author being able to tune in to, and select, a large number of discrete 'voice channels' on a radio, while postmodernism is more like hearing cross-talk across a number of channels all at once. 
In summary, Poeclectics expresses a wide-ranging diversity and plurality in poetic voice. It serves:

(1) the desire to investigate the tangents and outbacks of creative self; and

(2) to register deep uncertainties over canon-making and any rigidly held author perspective.

This is perhaps as close as we can get to a brief theory for Poeclectics. I concede, absolutely, that its description is coloured by my own interpretation and reading of British poets. I should also add that my application of the term principally to poetry (a focus I retain throughout this paper) does nothing to suggest that it may not also reflect a wider tendency across contemporary literature.

\section{Plural Voice and the Collaborative Self}

The growth of Poeclectics is apparent in the now ubiquitous creative writing exercise: 'Try (re-)writing this piece in the voice of $X^{\prime}$. Poeclectics absorbs, too, that new drive in poetry gathering behind the spoken word, particularly through the energetic diversity of such groups as Apples and Snakes and ShadoWork (Crucefix, 2003). My work with the latter group (Petrucci, 1999a) has led to a variety of innovative vocal contexts and collaborations. Recent examples include intercutting classic war poems so they can converse on stage, and Thames (a sequence composed for a Year of the Artist project in the London Borough of Havering) which 'translates' the geology of the Thames Basin into a series of voices whose various tones, styles and rhythms attempt to capture the personalities of the different types of soil in that area.

Thames (Petrucci, 2002) alludes to such registers as business-speak, cockney and scientific analysis and is thus 'polyvocal' (Box 1). It also contains anarchic segments in the voice of a geological 'erratic' which generates humour and irony through a blatant mismatch between form and content (Box 2, right entry). From the outset, I composed Thames with one ear open for its 'multi-vocal' delivery on stage via the ShadoWork group. Such use of multiple/multiplied speech cannot be reduced to a series of 'silly voices' adopted by writer-performers for cheap performance effect; rather, this activity felt to me like a lengthening of stride into uncharted unconscious territory, a process assisted by the 'co-vocal' collaborative context of ShadoWork. Multi-vocal and co-vocal interactions between writers (or even the use of one's own voice across a range of styles, speeds, accents and tones) are still underutilised in poetry, partly because (I think) we tend to devalue them. Which is a pity, because so many possibilities (Poeclectic and otherwise) remain untapped and unexplored to contemporary writing and performance simply through the paucity of collaborative activity on the scene. 


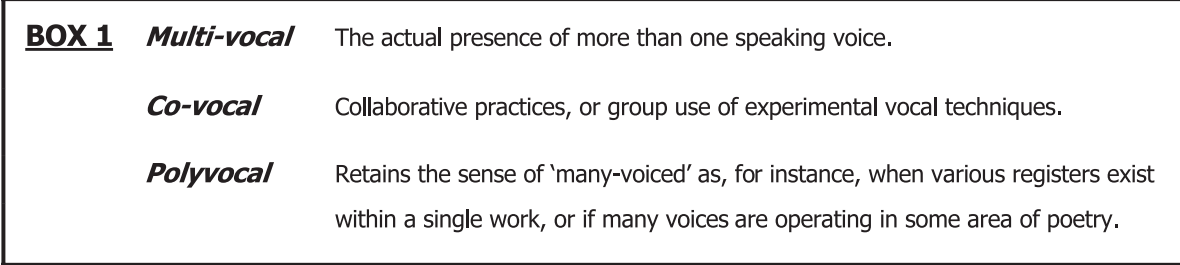

\begin{tabular}{|lll|}
\hline BOX 2 TRENCH & Extract from THAMES sequence \\
$\begin{array}{l}\text { Sniper, Sniper, in your tree - } \\
\text { has your eye closed in on me? } \\
\text { Did your sights hot-cross my head } \\
\text { before you chose young Phil instead? }\end{array}$ & $\begin{array}{l}\text { "Don't take your bones for granted - } \\
\text { someone might find them someday. } \\
\text { If looks could kill, would I be dead? }\end{array}$ & 'porosis might get in the way. \\
$\begin{array}{l}\text { Sniper, Sniper, the one you get } \\
\text { doesn't hear your rifle crack. }\end{array}$ & $\begin{array}{l}\text { So, make the scientist happy - } \\
\text { They're saying here that you've the knack. } \\
\text { They're telling me I've lost a bet - } \\
\text { they say I'm dead. I just don't know it yet. }\end{array}$ & $\begin{array}{l}\text { In a million years you'll be famous } \\
\text { in some Museum's catalogue." }\end{array}$ \\
& (tune based on: 'When Irish Eyes Are Smiling') \\
\hline
\end{tabular}

\section{Funding; Site-Specific and 'Self-Performing' Work; the Identity Industry}

Poets may well accommodate more of the plural self in their freelance work; but they also need accommodation! The relationship between creative self and self-support is as important as ever, and Poeclectics seems to serve (as well as reflect) the growing variety and quantity of financial packages now available to poets in public, community and semi-commercial situations. Poets are increasingly hired for off-the-page activities, not only within academe but also via various shifts from academy to street. Many case studies were aired, by practitioners, at the National Association for Writers in Education (NAWE) 2004 conference on Writing and Place held at Strawberry Hill in the UK, for instance Sarah Wardle's recent work (Wardle, 2004) at Tottenham Hotspur Football Club. One also thinks of poets involved in: commerce and business; university seminars, schools and school assemblies; public institutions and voluntary agencies; collaborations with musicians and the visual/plastic arts; the media; commemorative scenarios and civic events; community centres, hospitals, prisons, parks, forests, public transport, museums, oil-rigs and fish-n-chip shops... You name it - a poet has probably been there! Poets can now capture significant (though not overwhelming) pots of public money though such projects. Cases in point include: Sue Hubbard's immense IMAX 
poem, stencilled along the entire length of the Waterloo underpass in the heart of London; and my own contributions of 'multi-captions'/'collaged' captions (Petrucci, 1999b) at the various sites of the UK's Imperial War Museum (Figure 1). Such work may utilise writing/literature in order to frame (and interact with) an artefact or public space. Or the writer may be receptive to the techniques and dialogues of visual art, allowing these to engage the process of composition and the means of presentation. I term such areas of activity collectively (though loosely) as 'LiterARTure' (Petrucci, 2005).

Another example of LiterARTure is the Imperial War Museum's Poetry Hunt (entitled Search and Create) funded through the Poetry Society's Poetry Places scheme and still current at the Lambeth site in London. Trench is a keystone item in Search and Create (Box 2, left entry; Figure 2). It involves a telescopic sight down which, almost invariably, visitors cannot resist looking: whereupon they see the poem fixed to a distant pillar. Trench has been designed to create a synaesthetic space in which text, reader and environment draw on one another for new associations and resonances. The poem extends itself into - and is conditioned by - the optical system of the telescope, an interaction underscored through careful siting of the poem. Most notably, its line of sight was made to intersect, at about head-height, a flight of stairs (now removed) used heavily by visitors. There are also strong resonances between the poem's structure and the act of viewing, stressed visually and sonically through certain formal aspects of the piece: hard end-rhymes emphasise a sniper-like scanning of the eye, while the familiar sonic naivety of the opening lines
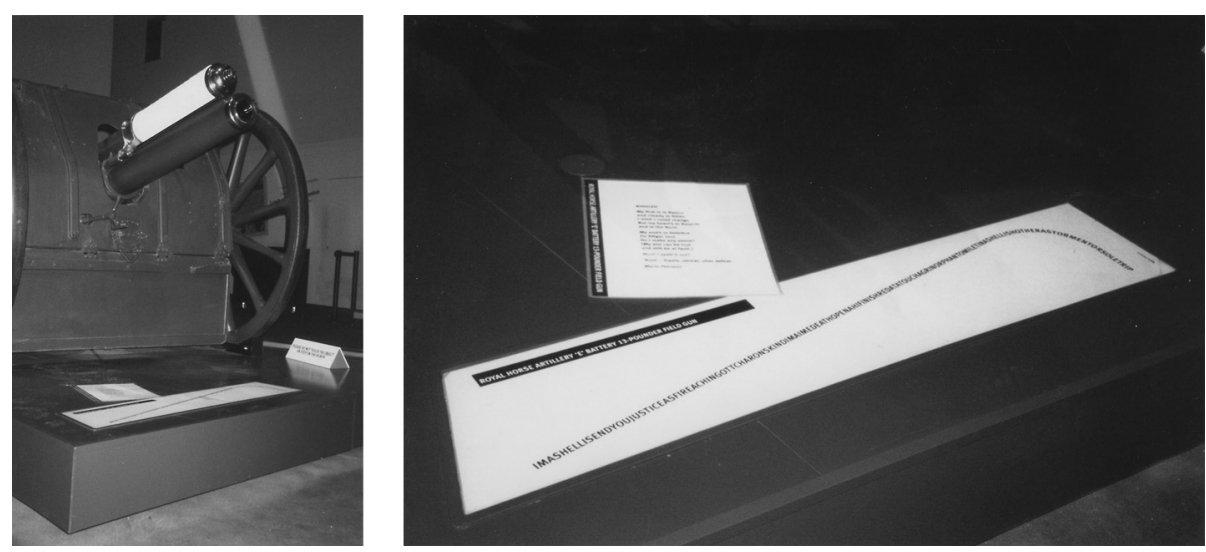

Figure 1 Imperial War Museum North (Trafford Park, Manchester, UK). A concrete poem by Mario Petrucci draws attention to the 'personality' and uncertainty of shell trajectories. The poem consists of 137 letters in a 'string', which can be read in many different ways depending on how the reader chooses to break up the sequence. It thus functions on a number of levels simultaneously: as a textual stimulant within the visitor's apprehension of the artefact; as an educational and literacy tool for visiting schools; and as aesthetic experience in its own right. Credit: Sam Heywood \& Mario Petrucci (2002). 


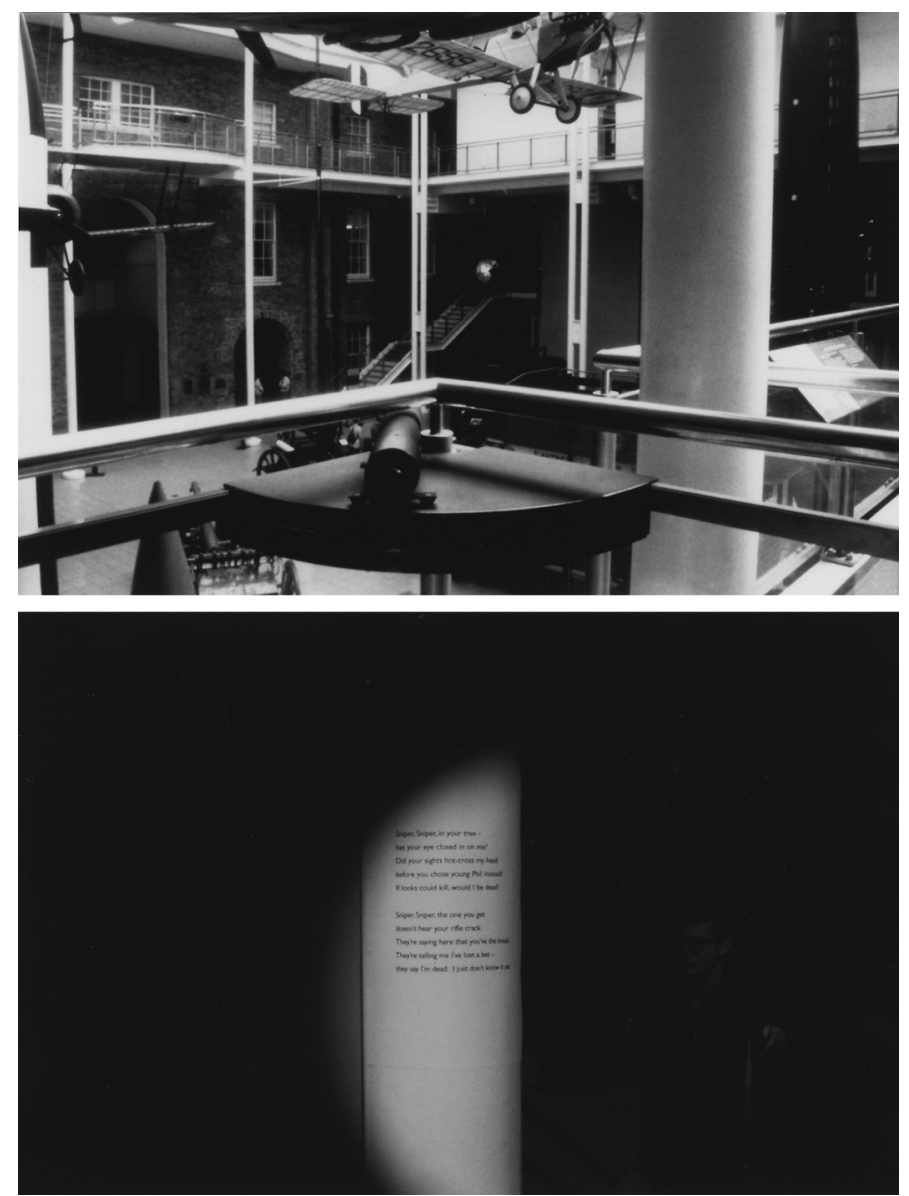

Figure 2 Trench. Imperial War Museum (Lambeth Road site, London, UK). By kind permission of the Imperial War Museum.

(listen out for Twinkle Twinkle Little Star) creates in the mind an eerie echo chamber for the morbid 'game' the soldiers are playing - a factor I feel sure contributes to the distinct sense of vulnerability and unease expressed by some viewers.

Trench must survive its highly charged museum context without me. I cannot introduce it (as in a reading or lecture) to its high-turnover audience. This is, of course, also true of poems on a library shelf; but there are greater expectations placed on something like Trench, perhaps, to 'perform'. Naturally, all texts arrive in our minds through some actual or implied performance, even if it is simply that inner voice of silent reading; but I maintain that a piece such as Trench can achieve, in some respects, a heightened sense of delivery by virtue of its unfamiliar setting and the visual and spatial potency of its surroundings. One might say Trench is a performance poem without a performer; it is, in a sense, 'self-performing'. And yet, the poem bears my identity along 


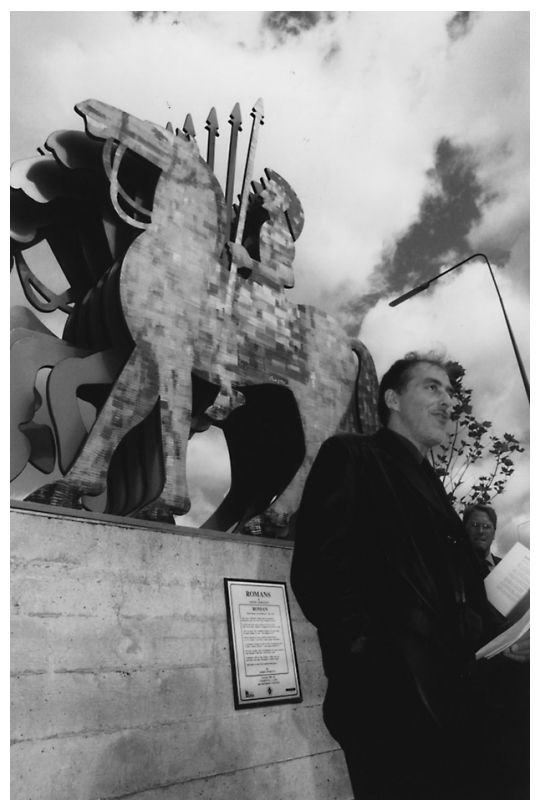

Figure 3 Year of the Artist project. Mario Petrucci's poem Roman both frames, and is framed by, David Gerstein's new sculpture at Gallows Corner, Romford (UK) sited on the old Roman road now known as the A12. Credit: Mario Petrucci.

with it - in a Poeclectic way - by embodying various aspects of my personal history and through the choices I made concerning its content, form and voice.

There are signs that 'self-performing' work like this is gaining wide acceptability. For instance, the Poeclectic set (Petrucci, 2002) of which Thames forms a key part has received considerable attention (including the Essex Best Fiction Award 2000-2002) and not just in conventional book form. Various poems have also been: sited in public (Figure 3); gigged multi-vocally; used for a 'Thames Walk' through the parks of Havering; and deployed in university seminars and conferences ... My point here is that this is precisely the type of extended remunerative matrix into which poetry may increasingly step - with or without its author - particularly if paper poetry goes into decline. This Poeclectic overlapping of boundaries and function may also begin to draw greater literary-academic rewards and grants, through such agencies as (say) Arts Council England and the UK's NESTA (National Endowment for Science, Technology and the Arts). At the same time, it is clear that publicly funded projects are sharpening our focus on occasionality and variety, qualities Poeclectics is well suited to deliver. The largely ad hoc social and educational contexts of these projects do encourage an accessibility and self-sufficiency in the writing one might also characterise as Poeclectic. I can therefore envisage Poeclectic poems becoming more widely involved in public spaces and institutions as facilitators, dissenters, intensifiers, modifiers, refractors, activators. They 
will thus create new sites for re-reading, re-writing and the reconstitution of meaning: i.e. they will be used for education in its broadest, most democratic sense. But do such modes of composition and exposure (particularly the public siting of poems) indicate a more fluid and subversive writing community, or do they simply serve an Identity Industry that is cashing in on new market niches and the desire of writers to acquire greater market presence? I have no definitive answer to this (though I am tempted to say 'both'); what follows is an attempt to at least raise some of the related issues.

\section{Poeclectic Identities: Pros and Cons}

I sometimes worry if Poeclecticism is retrogressive. Does it constitute a denial of the inner personal voice? Do its methods cut across the grain of authenticity, or noisily trample those essential mysteries of creativity Charles Simic calls 'translations from the silence'? Although I am wary of the baggage that comes with such notions as 'authenticity' and 'essential', I do concede that a danger of Poeclectics - as with any writing - is that its pursuit of variety or newness could lead to the merely quirky, to gratuitous entertainment, easy cultural consumption or the instantly gratifying. The Poeclectic writer, like the Romantic, might well have nightmares about being endlessly hired to contribute in banal or predictable ways to shopping malls when they could be cementing instead the ramparts of the next Castle Duino. Indeed, those very qualities in Poeclectics that make it responsive, rich and subversive may also be susceptible to shallow marketing, to the facile, garish or fanciful.

None of this need transpire. A delight in range and high impact are common outcomes in Poeclectics, but there is no automatic descent into superficiality or gimmickry. The responsiveness of Poeclectics to plural situations and contexts does not have to drive it into either extreme of flitting flimsiness or overgeneralising realism. If we ensure that commissions do not gain a free pass onto page, plinth or dais by virtue of novelty or pragmatism alone, then Poeclectics will be a valuable means of generating all types of text (both on and off the page) as authentic communicative performance experiences. Furthermore, Poeclectic writers need not be trapped within (any narrow conception of) Poeclectics. They can, for instance, develop several creative modes - say, a conventional building of canon alongside more freewheeling experiments - thereby spreading any risk to their creative integrity (a move that would, of course, itself fall within the broader scope of Poeclectic practice). This type of poet is also well placed to seize upon fresh knowledge and perceptions as these emerge or are popularised (as with new developments in science), thus assisting their uptake into literary consciousness. Those familiar with Bakhtin's work might compare this process with 'novelisation' (Gregson, 1996: 7). In a myriad of ways, then, Poeclectics can seed richly inclusive activities around the public exploration of modern identity and epistemology, enacted through the many-lensed instrument of communities and individual artists. This liberating development would have 
particular impact in those community-conscious projects open to experimentation and play.

However, if (as mentioned earlier) collaborating voices in literature remain underappreciated, we curb a key Poeclectic mode that can really 'speak into' the public domain, one of the modes most naturally empowering, in fact, to those poets outside the mainstream who wish to challenge (yet not entirely demolish) the conventions surrounding identity and literary value. I must stress this positive political role for Poeclectic pluralism. It represents a democratising force steered towards mildly radical quarters. One can make strong connections, for example, between Poeclectics and recent reclamations in literary criticism of excluded voices. Poeclectics can also take advantage of the fractures opening up in a modern self gripped between (on the one hand) the fluid elusiveness of the postmodern and (on the other hand) the homogenising global political economy. Certainly, by constantly reasserting and re-inventing plurality, Poeclectics is able to explore the former, and to challenge the latter, simultaneously.

Poeclecticism is thus an important attempt to continue, into the 21st century, literature's on-going examination of the complexities and conflicts of consciousness. Poeclectic poets are, after all, working writers who utilise a profile of techniques freshly emphasised so as to reveal the affiliations, possibilities and inconsistencies of contemporary sensibility. Their approach serves to amplify, perhaps, the inadequacy of a single voice in expressing modern identity. They are dissatisfied, one might suggest, with the trick of producing a single me like a mysterious egg from behind the ear of a particular style. Instead, they juggle many eggs from varied fowl in full and precarious view. Poeclectics therefore makes its way to the heart of the paradox captured by the standard uses of that very word 'identity': identity as sameness or mathematical conformity versus identity as the unique, unrepeatable, radical self (our ID-entity, perhaps?) Given Britain's variegated contemporary experience of race, culture, sexuality, tradition, place and commerce, it makes sense that our poets should attempt to use all the materials, methods and styles at their disposal in order to express and explore the concomitant labyrinth of creative tensions and opportunities.

Meanwhile, on a more pragmatic level, I have the distinct impression that significant monies (viz. via Europe, the National Lottery, sponsorship, commerce) have been stacking up behind regeneration programmes and the cultural strategies of local councils. Often, site-specific art is a key feature in these projects. Poeclectics seems poised to meet this diverse and intricate challenge with success - though one should be wary of words like 'success', which are easy to pen but exceedingly difficult to engender as lived experiences. Exploring the self through art (privately as well as publicly) is no easy option. One thing lacking in this area is guidance and training (pace, among others, Linda France's Text and Public Art course at the University of Newcastle in the UK) and few writers are currently active across relevant genres as advisors or mentors. Not only that. A poet's approach, as well as sense of self, may be influenced by media/ popular feedback or through having to formulate and systemise 'reasons' or 
'outcomes' for their work in funding applications and project appraisals. This means participating artists may lose confidence or feel vulnerable, or wonder if their work is being assimilated in some inappropriate way. (I was offered a .COMmission recently, inviting me to help establish [what seemed to me] a dodgy .COMmunity of 'writers' in cyberspace. Feeling awkward and .COMpromised, I turned it down.) Writers working in communal or educational settings can therefore face very real threats to their desired modes of self-expression, whether they are asked to read a poem at school assembly or to help launch a new product.

We must, as a consequence, draw greater attention to conflicts which may arise between artists, administrators and participants over commissions. Of course, many projects run with barely a hitch; but how does a writer cope, for example, with the reactionary miasma (and the anxiety) sometimes surrounding a commission involving monumental art or a heritage site? To whom can a freelance poet turn when torn between: private artist versus public/collaborative performer; creativity as an artist's personal (re-)creation versus the public's thirst for recreation; open-ended, unpredictable, unconscious artistic processes versus an institution's drive for targets, accountability or closure; an individual artist's aims versus the collective pressures of syllabus, education remit or government agenda? Because Poeclectics demands (in some sense, at least) both superfice and the entire self, it could intensify - as well as sublimate - such conflicts. Organisations like NAWE, along with seasoned freelance tutor-practitioners, could really help here - particularly in finding ways to facilitate the sharing of ideas and experience. Given the inherent diversity of this kind of work, and its sometimes knotty personal and creative implications, I suggest that the most suitable modes of assistance would be based more on open seminars and mentoring than on lectures and formal training programmes. It would, to my mind, be disastrous to quell the individual's response in favour of a raft of theories or a 'swatch-book' of proven commission approaches. I would rather see an engendering of aesthetic dialogues that respect individuality, innovation and (if pertinent) risk-taking whilst addressing the potential pragmatic and artistic pitfalls, where commissioned writers benefit from professional guidance in how to formulate strategies that dissolve the ego (so as to meet a variety of external requirements) whilst simultaneously reasserting the ego (to satisfy personal goals appropriately and with integrity).

Box 3 offers one example of the kind of seminar exercise that can be developed in order to explore such issues. True, Poeclectics is too openended for its future role ever to be entirely predicted, prescribed, or catered for, through a training course; but there is likely to be significant demand (at least potentially) for workshops and tutoring around the theme of public commissions, and considerable public terrain into which a skilled Poeclectic poet might venture. Consider, for instance, the bulldozed tabula rasa landscapes of urban redevelopment where one feels, with the writer Peter Scupham, 'acutely ill-at-ease' because 'now is the only dimension visible'. Poeclectics could help to reveal the history and culture watermarked across such sites. Moreover, by thus engaging 


\section{BOX 3}

\section{COMMISSIONS EXERCISE}

\section{INSTRUCTIONS ...}

- Divide group into pairs/ threes. HAND OUT COMMISSIONS (below) at random.

- Groups DISCUSS the commission: what issues might be raised between PERSONAL ARTISTIC GOALS, AESTHETIC CONSIDERATIONS and PUBLIC/INSTITUTIONAL expectations?

- Remember: no one is to actually write the commissions. You are merely exploring the issues.

- FACILITATOR KEEPS CONTEXTS VAGUE. Let groups invent the details themselves.

- Small groups REPORT BACK. Concerns / opportunities? Blessing or poisoned chalice?

COMMISSION 1 POEM/ TEXT for the PLINTH OF A SCULPTURE. Located: SHOPPING MALL in (say) LIVERPOOL.

COMMISSION 2 A new POEM for an AUDIO BOX to be used by visitors to POETS' CORNER, Westminster Abbey.

COMMISSION 3 New POEM in honour of a famous historical figure to be read (in character) at commemorating ceremony.

COMMISSION 4 New POEM/ TEXT in an ART GALLERY

to accompany a famous canvas of some antiquity.

$\underline{\text { COMMISSION } 5}$ A new POEM, for yourself, to illustrate your 'range' commissioned by a prominent literary festival.

$\underline{\text { COMMISSION } 6}$ POEM/ TEXT for a school's morning assembly.

COMMISSION 7 POEM/ TEXT for a plaque in a SCIENTIFIC/ ENGINEERING or MEDIA site (eg Royal Society, BBC... you decide all the details!)

COMMISSION 8 Either: COLLABORATING ON A LIBRETTO with a famous composer; or devising a COLLABORATIVE PERFORMANCE (with more than one reader or voice) for National Poetry Day (radio broadcast or TV).

the mosaics of the 'social self', Poeclectics is capable of exploring much more than individual identity; it can also galvanise innovative public placements to foster dialogue and insight across those linked cracks in the crazy-paving of communal identity. 
Correspondence

Any correspondence should be directed to Dr. Mario Petrucci. (mmpe trucci@hotmail.com).

\section{Note}

1. A version of this paper was presented at the NAWE (National Association of Writers in Education) Conference entitled 'Creative Writing and Identity' held at The Writing Centre, Middlesex University, UK (22 November 2003).

\section{References}

Crucefix, M. (2003) Working out of the shadows. Writing in Education 29, 38-40.

Duffy, C.A. (1999) The World's Wife. Basingstoke and Oxford: Macmillan.

Gregson, I. (1996) Contemporary Poetry and Postmodernism: Dialogue and Estrangement. Basingstoke: Macmillan.

Kennedy, D. (1996) New Relations: The Refashioning of British Poetry 1980-1994. Bridgend: Seren.

Petrucci, M. (1999a) ShadoWork - poets doing the unthinkable. Writing in Education 17, 27-29.

Petrucci, M. (1999b) Anaesthesia or Synaesthesia? Public Art Journal 1 (2), 15-17.

Petrucci, M. (2001) Poetry in performance: Intertextuality, Intra-textuality, Poeclectics. Paper presented at the Research Centre for Modern and Contemporary Poetry (Oxford Brookes University), 2-3 April 2001. On WWW at http://ah.brookes.ac. uk/english/staff/petrucci/poeclectics.html and http://mariopetrucci.port5.com/ otherwork.htm. Both accessed 7.6.05.

Petrucci, M. (2002) The Stamina of Sheep (The Havering Poems). Havering and Enfield: The London Borough of Havering \& Bound Spiral Publications.

Petrucci, M. (2005) Entry on 'LiterARTure'. On WWW at http://mariopetrucci.port5. com/iwm.htm. Accessed 7.6.05.

Shapcott, J. (1998) My Life Asleep. Oxford: Oxford University Press.

Shapcott, J. and Sweeney, M. (eds) (1996) Emergency Kit: Poems for Strange Times. London: Faber \& Faber.

Wardle, S. (2004) Audere est facere: Writing in residence at Tottenham Hotspur football club. Writing in Education 33, 25-27. 